\title{
Brugerinddragelse: Buzzword, blålys eller bæredygtighed
}

\author{
Ti bud på, hvad der skal til, hvis brugerinddragelse skal lykkes på det \\ socialpsykiatriske område
}

\author{
Af Lise Lotte Helm *)
}

\begin{abstract}
Resumé
Denne artikel sætter fokus på, hvad der skal til, for at brugerinddragelse på det sociale område kan blive en realitet. Artiklens pointe er, at brugerinddragelse kun bliver bæredygtige tiltag, hvis den prioriteres og koordineres i en fleksibel implementering på alle niveauer i det samfundsmæssige system. Brugerinddragelse forbliver let et blålys eller et buzzword uden etisk substans, hvis ikke også de politiske og organisatoriske rammer for borgere og behandlere rummer reelle muligheder for fleksibilitet, kreativitet, differentiering og forandring.
\end{abstract}

Artiklen bygger på et aktionsforskningsprojekt vedr. organisatorisk brugerinddragelse på Holmstrupgård, en socialpsykiatrisk døgninstitution for unge og unge voksne i Region Midtjylland (Helm, 2020). Derud over bygger artiklen på to litteraturstudier. Det ene udarbejdet ifm. Ph.d.projektet, det andet i forlængelse af projektet. Tilsammen viser undersøgelserne, at det gennem afstemt kommunikation er muligt at inddrage borgerne i dialog og i beslutninger af organisatorisk karakter i det omfang lovgivning, standarder, institutionelle rammer, strukturer og forventninger giver plads til det, men at det omvendt også er disse faktorer, der direkte eller indirekte medvirker til at danne barrierer for brugerinddragelsen.

\section{Emneord}

Brugerinddragelse; organisation; psykiatri; institution; fleksibilitet; kommunikation; socialpædagogik; samskabelse

*) Lise Lotte Helm er ph.d. i pædagogisk psykologi og forskning og udviklingsmedarbejder ved Socialområdet i Region Midtjylland. 


\section{A. Indledning}

\section{Baggrund}

Diverse konventioner og politiske tiltag har i de vestlige lande, gennem de sidste tre årtier, i tiltagende grad sat fokus på brugerinddragelse ${ }^{1}$. Intentionen er, at borgerne skal inddrages og have indflydelse på deres egen (sags)behandling.

Hvor formålet i 1980'erne udsprang af især etiske og demokratiske idealer, har det igennem de seneste år fået et mere tungtvejende samfundsøkonomisk sigte. Således kan brugerinddragelsen i Danmark også være et legitimt politisk redskab i omdefinering af den generelle forståelse af dansk velfærd. Borgerne skal også ansvarliggøres ift. at prioritere ressourcerne i det offentlige danske social- og sundhedssystem. Således er diskursen og idealet om brugerinddragelse blevet udvidet med begrebet samskabelse, der lægger sig op af en bred folkelig, demokratisk opfattelse af, at vi som individer har brug for sunde meningsbærende aktiviteter og sociale relationer. Det er dokumenteret, at brugerinddragelse, der øger 'patient-tilfredsheden' og brugernes selvværd, også kan medvirke til at nedbringe økonomiske udgifter ifm. indlæggelsestid samt øge brugernes muligheder for rehabilitering.

\section{Nye perspektiver og sprog}

Fra politikere og myndigheders side tales om velfærd på nye måder: "Kommunen vil traede et skridt tilbage og lade borgerne komme til" (Bundsgaard 2016)². Der arbejdes på en ny diskurs omkring velfærdsbegrebet karakteriseret som et storstilet kulturelt samskabelses-projekt. Eksempelvis har man i Aarhus kommune ligefrem udarbejdet et nyt vokabularium (Aarhus kommune, 2016), hvor fx ordet "service" tænkes erstattet med "fællesskab", "ekspert" med "sparringspartner" og "hjælp" med "selvhjælp. "Permanent" bliver til "midlertidig", "taler om" bliver til "taler med". I regionalt regi illustreres inddragelsen og "et sundhedsvaesen på patienten proemisser" ved at placere "den aktive medborger" i toppen af en pyramide ${ }^{3}$ og det Sociale Tilsyn zoomer i tiltagende grad ind på inddragelsen af brugerne.

\section{Hvad med virkeligheden?}

Aktuelt lever mange mennesker med psykisk sårbarhed/psykiske lidelser og antallet af børn og unge, der har det mentalt dårligt og får en diagnose er stadigt stigende. Det er derfor vigtigt også at betragte brugerinddragelse i et perspektiv, der rækker ud over det enkelte individs eget-ansvar.

\section{Nye tilgange og barriere}

Der har da også inden for det psykiatriske og socialpsykiatriske område i en årrække været forsøg på implementering af brugerinddragelse bl.a. med baggrund i Den Danske Kvalitetsmodel. Dette især i forhold til borgernes indflydelse på deres egen behandling. 
Trods politiske statements og gode intentioner har undersøgelser vist, at borgerne generelt ikke føler sig tilstrækkeligt inddraget, og der er beskrevet en række barrierer og vanskeligheder i forhold til implementering af brugerinddragelsen.

Nogle studier indikerer, at det går fremad på det somatiske område, men af undersøgelser på psykiatriområdet fremgår det, at patienterne her ikke føler sig hørt og taget alvorligt i samme omfang. Dette kunne (bort-)forklares med borgernes manglende realitetssans eller angst i sociale sammenhænge, fx. ifm. stormøder eller konferencer, hvor borgeren pludselig forventes at være 'ekspert i eget liv'. Det centrale er, at der er behov for forudgående dialog med borgerne både individuelt og i grupper, hvis der reelt skal kunne samskabes omkring organisering og tiltag.

\section{Problemstilling}

Det må være et etisk ideal om at undgå, at psykisk sårbare mennesker, hvis udfordringer i forvejen kan bestå i angst for at indgå i relationer og sociale fællesskaber, bliver yderligere ekskluderet eller stigmatiseret gennem forventningerne til brugerinddragelsen.

Det er altså ikke et spørgsmål, om brugerne skal inddrages eller ej, men et spørgsmål om, hvordan brugerinddragelsen kan implementeres på måder, hvor borgerne oplever sig betydningsfulde i dialog og beslutninger, og med åbenhed omkring hvor og hvornår brugerindflydelse ikke er mulig. Problemstillingen bag Ph.d.-arbejdet var, hvordan vi, i overensstemmelse med politiske krav og humanistiske idealer, kunne sørge for at beboerne på døgninstitutionen, til trods for en række alvorlige psykiatriske diagnoser ${ }^{4}$, blev inddraget og taget alvorligt i kommunikationen. Dette på deres egne præmisser og på trods af, at nogle af dem ind imellem kunne virke 'psykotiske', 'utilregnelige' eller 'hjælpeløse'.

\section{B. Undersøgelsesformer, begrebsanvendelse og disposition}

\section{Undersøgelsesformer}

Det var oplagt at anvende aktionsforskning, idet aktionsforskning netop bygger på, at der ikke i traditionel forstand er tale om forskning om deltagerne, men med deltagerne som 'medforskere'. Idealet er inddragende og demokratiske processer, der helst kan fortsætte efter, at den faciliterende forsker har forladt feltet (Reason \& Bradbury, 2008). Aktionsforskningen var i dette projekt inspireret af fremtidsværksteder som foregrebet utopi (Paaby, Nielsen \& Nielsen, 1988) kombineret med dramaturgisk praksis, teori og erfaring (Helm, 2017; Szatkowski, 2019). Således var også rammen for projektet inspireret af en kollektiv teaterproduktionsform kaldet Konceptuel Devising ${ }^{5}$. Aktionsforskningsprojektet blev fulgt op af en analyse baseret på filosoffen Michel Foucaults dispositivbegreb (Foucault, 1978; Helm, 2020) ${ }^{6}$. 
Som optakt til projektet blev udarbejdet et omfattende internationalt litteraturreview over videnskabelige studier vedr. brugerinddragelse på det (social)psykiatriske område med særlig opmærksomhed på Danmark og Skandinavien (Helm, 2020). Foranlediget af projektet blev efterfølgende udarbejdet et andet litteraturstudie med formålet at afdække eksisterende viden ifm. sociale, pædagogiske og samfundsmæssige perspektiver og tilgange til (social)psykiatrisk behandling (Helm, 2021).

De to litteraturstudier viste sig på mange områder at understøtte den læring, der blev skabt gennem aktionsforskningsprojektet. Litteraturstudierne understregede en tæt kobling mellem individuel og organisatorisk brugerinddragelse, idet der er behov for dialog og brugerindflydelse på organisatorisk niveau, hvis rammerne for den individuelle brugerinddragelse skal blive hensigtsmæssige, dvs. således at den individuelle brugerinddragelse og behandlingsarbejdet også tilretteloegges på brugernes præmisser.

Det var en intention i aktionsforskningsprojektet at undgå 'belastende' ansvarliggørelse af beboerne. Formålet var ikke 'forandring' for enhver pris, men at afprøve nye muligheder for samskabelse, der kunne balancere beboernes deltagelse. Projektet handlede om at sætte især beboernes erfaringer og praksisviden i spil gennem ikke- angstprovokerende social/organisatorisk deltagelse. Dette for at give dem magt og muligheder for forandring, indflydelse på både situation og institution og dermed forbedring af deres livsmuligheder.

Der var i aktionsforskningsprojektet tillige en ambition om at involvere så mange beboere som muligt. 70 \% af beboerne på 6 af institutionens døgnafdelinger deltog da også under en eller anden form i projektet. Der blev udarbejdet et katalog, som indeholdt mere end 100 af beboernes ideer ønsker, drømme og forslag. Dette kom til at danne baggrund for den videre proces og dialog på mere end 30 møder med ledere, medarbejdere hhv. beboere. Især institutionens brugerråd påtog sig en meget aktiv rolle.

\section{Artiklens opbygning}

Artiklen refererer løbende til såvel det lokale aktionsforskningsprojekt som de to mere generaliserende litteraturstudier. Heraf det ene udarbejdet ifm. ph.d.-afhandlingen og det andet i forlængelse af afhandlingens konklusioner. Artiklens analytiske del tager afsæt i brugerperspektiver, som baggrund for diskussion af medarbejdernes roller og funktion. Efterfølgende anskueliggøres, hvilken betydning de institutionelle rammer og divergerende opfattelser af det sociale aspekt kan have ifm. brugerinddragelsen. I dette afsnit sættes desuden særligt fokus på socialpædagogikkens rolle og potentialer. Artiklens konklusion opsamler kort de erfaringer og den viden, der blev genereret gennem undersøgelserne og kommer med og ti bud på, 
hvad der skal til, for at brugerinddragelse kan lykkes på det (social)psykiatriske område samt en afsluttende perspektivering.

Citaterne i artiklen er fra aktionsforskningsprojektets utopiværksteder med institutionens beboere.

\section{Anvendelse af begreber}

- Brugerinddragelse er hyppigt anvendt og bruges derfor også i denne artikel. Begrebet er dybest set absurd, idet der egentlig er tale om, at borgeren, som det primære subjekt, involverer andre mennesker i sit liv. Her skal begrebet forstås som brugernes involvering i beslutninger vedr. deres egen behandling.

- Organisatorisk brugerinddragelse anvendes i artiklen inspireret af VIBIS, Videnscenter for Brugerinddragelse i Sundhedsvæsenet ${ }^{7}$ i betydningen: Inddragelse af brugere og deres viden i planlægning, organisering, udvikling og evaluering af institution og organisation. Brugerinddragelse indebærer potentielt indflydelse, hvilket dog ikke er en selvfølge.

- (Social)psykiatri skrives således i artiklen, idet en præcis afgrænsning er vanskelig ift. såvel sproglig som kulturel og tidsmæssig oversættelse. Dette gør sig gældende i såvel international som national sammenhæng.

- Borger/bruger/beboer/patient/klient/"ung"8: anvendes i flæng som 1.-personsbegreb, dog ofte i overensstemmelse med det konkrete felt, der refereres til. Artiklen fokuserer på borgere, der er psykisk sårbare/har psykiske vanskeligheder/psykiatriske lidelser.

- Integration er anvendt i betydningen "En person kan vaere inkluderet uden at vare integreret; men en person kan ikke voere integreret uden at vaere inkluderet" (Kristensen et al., 2007: s. 1). Integration forstås i artiklen som borgernes egen oplevelse af at tilhøre et meningsfuldt socialt fællesskab. 


\section{Perspektiver}

口 "Man bliver tit set på som en diagnose - ikke som personen bag"

口 "Selv et lille pip kan voere en stor ting. Så det er bare vigtigt, at det bliver hørt"

I aktionsforskningsprojektet var de unges deltagelsesprocent overraskende høj, idet mere end halvdelen af institutionens beboere medvirkede under en eller anden form. Det udarbejdede katalog omfattede både meget konkrete forslag og ønsker til forandringer af pædagogik, hverdag, organisering og strukturer.

Beboerne gav tydeligt udtryk for, at brugerinddragelse ikke blot handler om "at få sin vilje igennem", men først og fremmest om at føle sig hørt, værd at lytte til og taget alvorligt.

Både beboerne og deres pårørende udtrykte stor tilfredshed med projektet og kom med opfordringer til, at både projektdesignet og erfaringerne fremadrettet kom til at danne grundlag for såvel brugerinddragelsen som institutionens udvikling.

I lighed med, hvad litteraturstudierne viste, ønskede brugerne dialog og indflydelse både i forbindelse med deres behandling og beslutninger på det organisatoriske plan. I overensstemmelse med lovgivningen får brugerne ofte mulighed for at give deres mening til kende, men centralt er det, at de sjældent selv er med til at definere, hvad der er på dagsordenen.

Litteraturstudierne viser generelt, at psykiatriens brugerne ønsker fleksible og dynamiske organisationer og miljøer (Borge \& Hummelvoll, 2008; Ljungberg, Denhov og Topor, 2016; Solbjør et al., 2013; Treichler, 2015; Øye \& Skorpen, 2010) og tilsvarende fleksibilitet og differentiering fra de professionelles side.

Involvering og medbestemmelse bør foregå i det omfang og de perioder, hvor brugerne har overskud til det. Samtidigt skal der være mulighed for ansvarsfritagelse i perioder, hvor brugerne har det så svært, at de udelukkende har brug for omsorg. I denne afbalancering ligger risikoen for, at standarder og rutiner tager over, hvis ikke der eksisterer en høj grad af sensibilitet ift., hvornår brugeren igen magter og profiterer af at være inddraget både praktisk og i dialog og beslutninger. Tilsammen viser aktionsforskningsprojektet og litteraturstudiet, at brugerne finder det vigtigt at blive involveret og respekteret gennem inddragelse af deres egen viden og erfaringer i forbindelse med problemløsningsprocesser. Brugerne ønsker medarbejdere og rammer, der åbner mulighed for improvisation, kreativitet og samskabelse både hver for sig, i gruppesammenhæng og i forbindelse med organisatorisk inddragelse. 
Brugeres aktive deltagelse i forhold til behandlingsindsatsen er afgørende for graden af bedring og heling. Betydningen af, at brugerne også får mulighed for at få indflydelse på behandlingsmiljøers hverdag, planer, strukturer og organisering kan have markant betydning for de enkelte deltageres oplevelse af meningsfuldhed og udvikling af social identitet.

\section{Personalets roller}

- "Personalet skal ikke vare så bange for at prøve noget ift. at styrke vores udvikling hen imod opfyldelsen af vores ønsker og drømme".

口 "Der burde vaere en bagatelgraense for, hvornår personalet selv måtte tage en beslutning".

\section{Medarbejdernes roller}

De professionelle medarbejdere har en helt afgørende betydning ift. brugernes trivsel, udvikling, inddragelse og heling/recovery.

I forbindelse med aktionsforskningsprojektet virkede medarbejderne som udgangspunkt generelt meget positive og engagerede. Kun et par medarbejdere udtrykte sig skeptisk med begrundelsen, at de unge var for "syge" eller "dårlige" til at deltage eller kunne få "syg indflydelse".

Til trods for den interesse og det engagement, der i formelle såvel som uformelle sammenhænge kom til udtryk fra medarbejdernes side, gik det i praksis meget trægt med både information, motivation og deltagelse. Flere remindere af forskellige kanaler gav ringe resultat. Det viste sig således, at unge, der ikke havde deltaget i den introducerende dialog på husmøderne eller var nye på institutionen, slet ikke havde hørt om projektet. Dette trods diverse aftaler, mails, plakater og foldere.

I Ph.d.-afhandlingen angives en række mulige forklaringer herpå: Bl.a. Personalets vanetænkning, modstand mod forandring og forhåndsdefineret bedreviden, men også at medarbejderne oplever flere slags krydspres, hvor undvigelse kan ligge lige i kølvandet på frygten for afmagt, utilstrækkelighed og usikkerhed. - For hvem og hvad er det, der skal definere den 'gode' medarbejder på en socialpsykiatrisk institution?

Brugerne ønsker generelt, at medarbejderne har gode kommunikative evner, er empatiske, fleksible, sensitive og tillidsvækkende. De skal kunne differentiere og være nærværende og kreative i deres kommunikation og handlinger.

De professionelle medarbejdere kan imidlertid ofte være usikre på, hvordan de skal samarbejde/samskabe med borgerne og oplever, især i rigide organisatoriske systemer, et 
loyalitetsdilemma ift. bl.a. instrukser, dokumentation og strukturer. Dertil kan komme en ulyst ift. at stå ved og diskutere magtforhold i relation til borgerne.

Medarbejdernes dilemmaer kan i den konkrete kontekst, vel miljøterapeutisk, men stærkt domineret af det sundhedsvidenskabelige paradigme, resultere i en form dekobling ift. mere socialpædagogisk reflekterende, samskabende og samfundsrettede aspekter. I aktionsforskningsprojektet som i andre undersøgelser bliver nogle af systemets egne indbyggede barrierer for organisatorisk brugerinddragelse synlige.

Nogle studier (bl.a Cousse'e, et al., 2010; Linhorst, Eckert \& Hamilton, 2005) anbefaler, at det er medarbejdere uddannet indenfor det sociale område, der pga. deres kommunikative og faglige kompetencer, forestår især brugerinddragelsen på det (social)psykiatriske område. Under alle omstændigheder er det vigtigt, at der i organisationen og strukturen gives og fastholdes et myndigheds- og råderum for den enkelte medarbejders samspil med brugerne.

Det påvises desuden, at der er behov for både faglig og 'personlig' mangfoldighed i medarbejderstabens sammensætning, herunder bl.a. i forhold til uddannelse, alder, køn og 'type'. Især ønsker brugerne tydelighed og medarbejdernes gensidige respekt ift. inddragelse af professionelle med 'andre' faglige kompetencer.

\section{Ledelsen}

Ingen mellemledere problematiserede på noget tidspunkt højlydt aktionsforskningsprojektet eller dets formål. Tvært imod understregede de vigtigheden af brugerinddragelsens demokratiske idealer. Flere af mellemlederne formulerede dog efterfølgende, at det med brugerinddragelse var noget, de i praksis forventede medarbejderne tog sig af. De beklagede, at de selv, grundet andre opgaver og samtidigt iværksatte projekter, nok var kommet til at nedprioritere aktionsforskningsprojektet.

Topledelsen bakkede op omkring projektet gennem hele forløbet og opfordrede ved flere lejligheder mellemledere og medarbejdere til at engagere sig i projektet. De iværksatte dog samtidigt flere andre projekter, hvilket for nogle afdelingsledere kom til at udgøre forklaringen på den manglende prioritering organisatorisk brugerinddragelse. Projekter vedr. brugerinddragelse bør være i harmoni med andre projekter, der evt. søsættes i samme projektperiode, således at disse gensidigt kan befrugte hinanden.

Brugernes ønsker om mangfoldighed i medarbejderstaben udgør en klar forventning til ledelsen ift. sammensætningen af personalekorpset. 


\section{E. Institutionelle rammer og vilkår}

口 "Kortere ventetid på at få svar på forslag, kritik og forespørgsler giver følelsen af at blive taget alvorligt"

口 "Mere tid, hvor medarbejderne kommunikerer med - og ikke om - os"

\section{Organisatoriske rammer}

Der eksisterer i hierarkiske behandlingsmiljøer med høj grad af regelstyring og standardisering indbyggede forhindringer for den fleksibilitet, som brugerinddragelsen fordrer.

Især aktionsforskningsprojektets kompositionsfase stødte på flere udfordringer. Dette ikke så meget pga. uenighed omkring prioriteringen af ideer og forslag, men fordi, det gav store udfordringer overhovedet at etablere møder på tværs af organisationens faste strukturer, fx mellem unge fra forskellige afdelinger, medarbejdere og ledere.

Det lykkedes således kun delvis at indfri projektets formål. Grundlæggende fordi retten til at træffe beslutninger og magten til at forandre eksisterende strukturer var placeret hos ledere, politikere og administrationer, og således lå hos helt andre end de primært samskabende aktører, beboerne og medarbejderne.

De nævnte litteraturstudier bekræfter, at implementering af brugerdeltagelsen i etablerede institutionelle kontekster, hvor der netop kan argumenteres for at være stort behov for det, generelt set viser sig vanskelig. Organisatorisk brugerinddragelse fordrer dynamik og fleksibilitet i systemerne. Der skal være plads til improvisation, dialog og fællesskaber på tværs af organisationens segmenter og strukturer. Således kan alt for fastlåste 'møderul' og distancerede eller langstrakte hierarkiske beslutningsprocesser komme til at danne barrierer.

Miljøterapi ${ }^{9}$ byggede oprindeligt på brugerinddragende demokrati og medbestemmelse i den daglige og organisatoriske praksis omring psykisk syge og sårbare menneskers recovery. På baggrund af miljøterapiens transformation til det biomedicinske områdes mere positivistiske tænkning og hierarkiske strukturer advarer forskere imidlertid imod, at den udvikler sig til at blive en medicinsk standardiserings-teknologi frem for en samfundsrettet re-integrationsmulighed (Mathisen et al., 2016; Øye \& Skorpen, 2010). Disse undersøgelser påpeger i overensstemmelse med aktionsforskningsprojektet vigtigheden af, at brugerinddragelse ikke kommer til at stå i et modsætningsforhold til miljøterapien. Det anbefales derfor, at miljøterapien fastholder flere af sine oprindelige samskabende og samfundsrettede sociale og demokratiske idealer. 


\section{Repræsentativ brugerinddragelse}

Institutionens brugerråd påtog sig en aktiv rolle og havde i aktionsforskningsprojektet de bedste muligheder ifm. udviklingen af organisatorisk brugerinddragelse i institutionens eksisterende system. Her kunne dialogen nemlig foregå inden for de eksisterende strukturer og beboerrepræsentanterne fik mulighed for at kommunikere direkte med topledelsen. Brugerrådet var både under og efter projektperioden særdeles engageret og arbejdede som delprojekt med rådets egen organisatoriske udvikling.

Brugerrådssammenhængen gav desuden psykologisk set medlemmerne mulighed for både at blive betragtet og samskabe som individer (dvs. ikke som diagnoser) og samtidigt at opleve sig som betydningsfulde medlemmer af en (selvvalgt) gruppe.

Rådet markerede til en vis grad sin kulturelle position på institutionen, men foranledigede ikke umiddelbart forandringer af mere strukturel organisatorisk karakter.

En aktuel tendens til, at organisatorisk involvering af brugerne gennem repræsentativ inddragelse ${ }^{10}$ fx gennem brugergruppers møder med politikere, kan læses ud af bl.a. VIBIS', Videnscenter for Brugerinddragelse i Sundhedsvæsenets definition af organisatorisk brugerinddragelse. Denne blev i 2019 ændret fra "Inddragelse af brugere og viden om brugerperspektivet i planloegning, organisering, udvikling og evaluering af sundhedsvoesenet" (VIBIS, 2017) til "At give brugere indflydelse på udviklingen af sundhedsvoesenet gennem anvendelse af viden om brugerperspektivet og samarbejde med brugerreproesentanter (min understregning) $i$ beslutnings- og udviklingsprocesser.

I den sammenhæng, kan der være en risiko for, at de mindst ressourcestærke borgere og pårørende ikke bliver hørt. Det bliver helt afgørende, at repræsentanterne er i tæt dialog og solidarisk med den gruppe de repræsenterer. Dertil kommer betydningen af faglige perspektiver og ejerskab i de 'mellemliggende' lag, idet det ofte er medarbejdere, der skal motivere og katalysere inddragelse og gennemførelse af forandringer.

I det hele taget kunne flere tvaergående dialoger i det hele taget bidrage til at opfylde brugernes ønsker til både indflydelse og kontinuitet i det tværfaglige og tværsektuelle samarbejde.

Hvis den repræsentative form for brugerinddragelse skal udvikles inden for eksisterende organisationers rammer, kræver det personalets opmærksomhed på beboernes interne dialog og støtte ift. deltagelsen. Dertil kommer de grundlæggende pædagogiske udfordringer i samspillet med borgeren ift. fleksibel afbalancering mellem bl.a. omsorg versus ansvar, forudsigelighed versus variation og nærhed versus distance. 


\section{F. Perspektiver på de sociale aspekter}

口 "Man skal igennem et system, der er bygget op, så alting skal sattes ind i kasser. Passer vi ikke ind - maser man bare..."

口 "Man er et produkt, der skal komme foerdigt ud"

\section{Det sociale aspekt}

Da heling af sårbare borgeres selvbilleder og identitet oftest foregår i sociale og relationelle sammenhænge og de sociale aspekter udgør en central faktor i udvikling og behandling indenfor det socialpsykiatriske område, er det vigtigt ikke alene at registrere og forholde sig til dikotomier som syg eller rask og til behandlingsplaners succes-kriterier (modsat 'fiasko', forstås), men at fokusere på, hvad der sker i mellemrum og processer ift. kommunikation, pædagogiske og sociale samspil (Helm, 2017) og i brugerinddragelsen, hvor "[...] ressourcer til at etablere øvebaner og loering[...]" bør prioriteres (Digmann, 2018: s. 388).

I aktionsforskningsprojektet var et af de temaer, som både beboerne og personalet prioriterede højt, fokus på "Livet udenfor" og "Livet efter institutionen".

En hjørnesten i institutionens behandlingskodeks er den gængse, at beboernes sociale udvikling fremmes af den graduerede bevægelse fra en-til-en-relationen til det bredere sociale felt. Omvendt har tidligere projekter på institutionen dog påvist, at er der tryghed i en gruppe, som gennem et fælles tredje arbejder hen imod omkring den fælles anelse om et mål/produkt, kan der ofte ske overraskende diskontinuerte kvalitative spring i deltagernes psykosociale udvikling (Helm, 2013; Stern, 2000). Dette således, at beboerne pludselig magtede noget, som hverken de selv, behandlere eller pårørende havde turdet håbe på. Skal dette kunne ske fordrer det, at medarbejderne medvirker til at skabe en tryg, foelles anelse om, hvad fremtiden konkret kunne indebære (Kristensen, O.S. 2018 in pres.; Cox \& Klinger, 2011).

Hvis anelsen er for diffus, omfattende eller måske slet ikke fælles, opstår risikoen for, at der bliver tale om en 'bange anelse', hvorved brugernes behov for tryghed i den aktuelle ramme, den smalle relation og fastholdelsen i fortidens 'traumer' yderligere skærpes.

Den bio-psyko-sociale model, som dansk psykiatri refererer til, henter sin primære tyngde i biologien, dernæst psykologien og det sociale forstået som patientens individuelle samspil med omgivelserne i nutid og fortid. Både forståelsen og behandlingen på det (social)psykiatriske område domineres af det medicinske paradigme. Fremtrædende danske psykiatere definerer psykisk sygdom som "organiske eller kropslige forandringer og forstyrrelser" og "Psykiske symptomer genereres $i$ 
forloengelse af, at der er noget galt i enten hjernen eller kroppen" (Jørgensen, Bredkjær \& Nordentoft, 2012: s. 61). De anbefaler standardisering og harmonisering af diagnostik og behandling, mens sociale og pædagogiske tiltag nævnes som "periferydelser" (Ibid.: 109). Således ligger den moderne psykiatri i Danmark langt fra en socialvidenskabelig og samfundsmæssig forståelse af psykisk sårbarhed. Dette får ikke alene betydning ifm. selve behandlingen, men også ift. forebyggelse af psykisk sårbarhed (Hjortkjær, 2020; Katzenelson et al., 2019).

En lang række skandinaviske studier argumenterer for et bredere socialt orienteret og mere samfundsrettet perspektiv, blik for borgernes forskellighed og øget opmærksomhed på diskursen og kommunikationen med borgerne med formålet at skabe en mere ligeværdig dialog (Andersen, Larsen \& Ulland, 2015; Lihme, 2015; Ljungberg, Denhov \& Topor, 2016; Rise et al., 2014; Sommerseth \& Dysvik, 2008; Øye \& Skorpen, 2010; Priebe, 2016; Priebe et al., 2011; Priebe, Burns \& Craig, 2013; Corrigan et al., 2012).

Tendensen er, at det bredere sociale perspektiv, der indebærer refleksionen over det dialektiske forhold mellem individ og samfund, først rigtig estimeres og sættes i spil ifm. med den recovery og bostøtte, der skal effektueres, når psykisk sårbare borgere efter endt institutionsophold hurtigst og bedst muligt skal inkluderes og helst integreres i civilsamfundet. Dette ofte som en del af arbejdsmarkedspolitikken ifm. aktivering af borgerne (Jensen, 2016; Torfing, 2004).

Der eksisterer en risiko for, at den socialpsykiatriske institution bliver fastholdt som et relativt afsondret klinisk rum, hvilket da også får nogle forskere til at stille spørgsmålet, om den moderne psykiatri overhovedet er på rette kurs (Murphy \& Joseph, 2019; Rose, 2019; Warming, 2019). Ikke alene efter, men også under institutionsophold bør værdsættelse af den samfundsmæssige sociale og socialpædagogiske dimension betragtes som en vigtig og ligeværdig del af behandling og recovery. Her bliver forståelse og prioritering af fokus på samspil med det omgivende samfund og inddragelse på brugernes præmisser og indflydelse på også det organisatoriske plan af særlig betydning. Pædagogisk tilrettelæggelse, motivation og relationer, der lægger op til og stimulerer borgernes mod til deltagelse, diskussion og indflydelse skal prioriteres. For, som det er fremgået, kan selv et lille, forsigtigt "pip" og reaktionen/responsen herpå, have afgørende betydning for den psykisk sårbare borger.

\section{Socialpædagogikkens rolle}

En række undersøgelser anbefaler en mere socialvidenskabelig tilgang til det psykiatriske arbejde (Murphy \& Joseph, 2019; Priebe, Burns \& Craig, 2013; Rose, 2019) og nogle, at fagprofessionelle med en social og pædagogisk tilgang kan være de bedst kvalificerede ift. at skabe relationer og inddrage brugerne. Socialpædagogik, der bygger på pædagogik og en kombination af psykologi og sociologi, opfylder ønsker om fagprofessionelle, der er stærke i det kommunikative, relationelle, 
brugerinddragende og samskabende felt. Det ser imidlertid ud til, at socialpædagogikkens rolle og refleksioner i et samfundsmæssigt perspektiv i tiltagende grad reduceres til kompenserende og individualiserende special- og medicinpoedagogik.

Hvor det medicinske fagområde møder socialpædagogikken, oplever de pædagogisk uddannede medarbejdere ofte, at deres faglighed domineres af den medicinske (Rothuizen og Boldsen, 2016). Hvis den institutionelle kultur skal udvikles til borgernes bedste, kræver det gensidig respekt og ligeværdig dialog de forskellige paradigmer og traditioner imellem. Sundhedsområdet har det umiddelbare fortrin at være målbart, konkret, og tydeligt, mens socialpædagogikken er en kulturel og praksiskvalificerende ressource ift. kommunikationen med borgerne.

Mange mennesker kommer sig efter en sindslidelse eller bliver bedre til at leve med deres psykiske sårbarhed, men erfaringen viser, at det ofte er de sociale følgevirkninger i forbindelse med psykisk sårbarhed og sygdom, der på længere sigt volder problemer og kan virke invaliderende. Bl.a. derfor kan oplevelser af at have en plads og betydning i den relationelle, sociale og organisatoriske kontekst rumme potentialer for både mental og social udvikling. Det kan derfor anbefales, at den socialpædagogiske profession bliver mere eksplicit og tydelig omkring, hvilke kompetencer og hvilket refleksionsparadigme, der karakteriserer fagfeltet, og som bør udvikles på baggrund af sine egne værdier. Socialpædagogik på det socialpsykiatriske område må ikke blot komme til at handle om implementering af nye metoder i en lind strøm eller forsøg på at iklæde sig den 'hvide kittel'.

\section{G. Konklusion, ti bud og perspektivering}

\section{Konklusion}

Projektet bekræftede forventningen om aktionsforskningens potentialer ift. undersøgelse af mulighederne for brugerinddragelse.

Projektet viste, at det gennem fleksibel og dynamisk kommunikation var muligt at inddrage beboerne i dialoger omkring de organisatoriske forhold. Projektet medførte en vis manifestation af det lokale brugerråd og en vis kulturel udvikling i form af øget opmærksomhed på at inddrage beboerne i dialoger og beslutninger af især konkret og praktisk karakter. Såvel medarbejdere som ledere gav udtryk for demokratiske idealer og for vigtigheden af organisatorisk brugerinddragelse, mens forandringer af organisationens og hverdagens rytmer og strukturer viste sig vanskelige at gennemføre.

Projektet påviste desuden behovet for transparens, udvikling og formidling af socialpædagogiske og sociale aspekter. Dette sås bekræftet af en række studier, der argumenterer for organisatorisk 
brugerinddragelse og et generelt mere samfundsrettet perspektiv i forståelse og behandling af psykiske lidelser, også under institutionsophold.

Aktionsforskningsprojektet og litteraturstudierne viser tilsammen, at der ofte er et modsætningsforhold ift. lovgivning, organisering og strukturer, som skaber barriererne for brugerinddragelse. Implementering og udviklingen og af såvel den individuelle som organisatoriske brugerinddragelse bør indgå som en del af den daglige drift og fordrer derfor mere fleksible strukturer, organisationer og miljøer, diskursive forandringer og større transparens og ligeværdighed i diskussionen mellem sundhedsvidenskabelige, humanistiske og samfundsvidenskabelige fagprofessioner og paradigmer.

Især socialpædagogikken, der har blik for det sociale, også forstået i et samfundsmæssigt perspektiv, ser ud til at mangle råderum til fleksibel og kreativ samskabelse ${ }^{11}$ med borgerne og formidling af et mere alsidigt recovery- og dannelsesbegreb. Der er behov for manifestation, udvikling og formidling af en bredere samfundsreflekterende faglig forståelse af (social)psykiatri indenfor behandlingsinstitutionernes rammer, hvis 1) brugerinddragelse skal kunne implementeres 2) brugernes overgang fra institution til civilsamfund skal kunne blive lettere og mere smidig og 3) der skal ske en forbedring af borgernes muligheder for recovery, inklusion og social integration i et samfund, hvor der i forvejen kunne ønskes bedre betingelser for forebyggelse og afstigmatisering.

Konklusionen er, at reel og bæredygtig brugerinddragelse kræver mod til forandring. Dette ikke alene fra brugere og medarbejderes side, men også fra politikere, myndigheder og ledere. Brugerinddragelse fordrer socialpædagogisk faglighed ift. både tilrettelæggelse af og kommunikationen med borgerne samt kontinuerlige refleksioner over forholdet mellem borger og samfund. Dette kan kun udfolde sig med en højere grad af strukturel fleksibilitet i og omkring de sociale organisationer.

Undersøgelsernes fund er nedenfor sammenfattet i 10 bud på, hvad der skal til, hvis brugerinddragelse på det (social)psykiatriske område skal lykkes.

\section{Ti bud om brugerinddragelse}

1) Borgerne bør mødes med respekt og ligeværdighed som individer og ikke som diagnoser, således at de føler sig set, hørt og taget alvorligt.

2) Organisatorisk brugerinddragelse skal sikre, at den individuelle brugerinddragelse og behandlingsarbejdet også foregår på brugernes præmisser. 
3) Borgerne bør mødes af dynamiske fagpersoner, der er gode til at kommunikere, opfange signaler og skabe relationer samt lægger op til og stimulerer borgernes mod til social deltagelse, diskussion og indflydelse

4) Behandlingsmiljøer, institutioner og organisationer bør fungere dynamisk og fleksibelt, således at borgerne får mulighed for indflydelse, men samtidigt også kan fritages for ansvar i perioder, hvor borgeren har brug for dét.

5) Det er ikke tilstrækkeligt, at brugerinddragelse alene fungerer i et politisk samarbejde med ressourcestærke brugere og pårørendeorganisationer. Organisatorisk brugerinddragelse bør implementeres i institutionernes daglige drift, således at borgerne får mulighed for medindflydelse ift. behandlingens rammer, teknologier og strukturer.

6) Der bør sikres (pædagogiske) råderum til uformelt socialt samvær, dialog, improvisation og aktiviteter i samskabelse med borgerne.

7) Der bør i institutioner og organisationer lægges op til åbenhed og tværgående dialoger omkring eksisterende/oplevede magtforhold samt muligheder og begrænsninger i disse.

8) Der bør være kontinuitet, gensidig respekt og samarbejde i og på tværs af niveauer, instanser, systemer og faggrupper samt tydelighed ift. de forskellige medarbejderes kvalifikationer og diverse instansers kompetencer. Brugerinddragelsen kan bl.a. styrkes ved, at den socialpædagogiske dimension i institutionerne tydeliggøres, udvikles og manifesteres samt indgår i ligeværdigt samarbejde med de øvrige, bl.a. sundhedsfaglige professioner.

9) Der bør være et øget fokus på udfordringerne omkring transition og gives mere socialpædagogisk myndighed, forstået i dobbelt forstand som både pædagogens myndighed ifm. at tage vare på borgeren og det at støtte borgeren i at udvikle sin myndighed (Wiberg, 2017). Begge dele med formålet at udvikle og skærpe blikket ift. de sociale og samfundsmæssige aspekter, hvori borgeren senere ikke alene skal inkluderes, men også helst integreres. Med andre ord: et større fokus på samfundsmæssige perspektiver og borgerens sociale integration også under selve institutionsopholdet.

10) Brugerinddragelse bør prioriteres holdnings- og ressourcemæssigt af både politikere, myndigheder og ledere, således at organisatorisk brugerinddragelse kan blive en 'skalopgave'.

\section{Perspektivering}

Det årelange arbejde med udvikling af brugerinddragelse inden for de eksisterende strukturer, rammer og organisationer på det sociale område kan naturligvis fortsætte. Hvis udviklingen imidlertid skal ske i en sådan grad, at områdets brugere reelt kommer til at føle sig set, hørt og taget alvorligt, bliver det nødvendigt, ikke alene at diskutere, men også at forandre/smidiggøre nogle af 
de eksisterende strukturelle konstruktioner og organisatoriske processer i og omkring institutionerne.

Overordnet anbefales det, at der anlægges et langt mere socialvidenskabeligt perspektiv på det sociale/socialpsykiatriske område og at de grundlæggende sociale, samskabende og samfundsmæssige dimensioner i det nuværende behandlingssystem udvikles og formidles. 


\section{Referencer}

Andersen, A.J.W., Larsen, I.B., \& Ulland, E. (2015). Bidrag Til En Ny Praksis? - Utvikling Og Forskning i Psykisk Helsearbeid Ved Universitetet i Agder i Perioden 2008-2013. Tidsskrift for psykisk helsearbeid 11.1 (2015): 4-16. https://doi.org/10.18261/ISSN1504-3010-2015-01-02

Borge, L., Hummelvoll, J.K. (2008). Patients' Experience of Learning and Gaining Personal Knowledge During a Stay at a Mental Hospital. Journal of psychiatric and mental health nursing 15.5: 365-373. https://doi.org/10.1111/j.1365-2850.2007.01237.x

Corrigan, P.W., Morris, S.B. Michaels, P.J., Rafacz, J.D. Rüsch, N (2012) Challenging the Public Stigma of Mental Illness: A Meta-Analysis of Outcome Studies. PSYCHIATRIC SERVICES, October: Vol. 63 No. 10: 963-973. https://doi.org/10.1176/appi.ps.201100529

Cousse' e, F., Bradt, L., Roose,R. \& Bouverne-De Bie, M. (2010). The Emerging Social Pedagogical Paradigm in UK Child and Youth Care: Deus Ex Machina or Walking the Beaten Path?. British Journal of Social Work 40: 789-805. https://doi.org/10.1093/bjsw/bcn147

Cox, W.M. \& Klinger, E. (2011). Motivation and the Theory of Current Concern. Handbook of Motivational Counseling. Cap. 1, 3. Sussex: John Wiley \& Sons, LTD. https://doi.org/10.1002/9780470979952

Digmann, A., Nielsen A.M. \& Ejlersen, L.S. (2018). Dem der siger, at det ikke kan lade sig gøre, skal lade vær' med at afbryde os, der allerede er i gang. Samfundslederskab i Skandinavien, Årgang 33, Nr. 5: 369-393. https://doi.org/10.22439/sis.v33i5.5633

Foucault, M. (1978). Sexualitetens Historie, Bind 1, Viljen til Viden, København: Forlaget Rhodos Foucault, M. (1980). The confessions of the flesh, i Power/Knowledge. New York: Pantheon Books Helm, L.L. (2009). Gobelinens liv. Masterafhandling i Social Integration. Psykologisk Institut. Aarhus: Aarhus Universitet

Helm, L.L. (2013). Teater træner evnen til at mentalisere, Psykoterapeuten $n r$. 3, oktober 2013: 1421

Helm, LL. (2017). Fra dramaturgi til pædagogik: et bidrag til socialpædagogikkens semantiske udfordring, Tidsskrift for Socialpoedagogik, nr. 2, p: 57-70. Hentet på:

https://socialpaedagogik.dk/udvalgte_artikler/lise_lotte_strandgaard_helm_petersen__fra_dramat urgi_til_paedagogik.pdf

Helm, L.L. (2020). Organisatorisk brugerinddragelse på en socialpsykiatrisk døgninstitution: Et dramaturgisk inspireret aktionsforskningsprojekt. AU Library Scholarly Publishing Services. Hentet på https://ebooks.au.dk/aul/catalog/book/383 
Helm, L.L. (2021). Socialpædagogikken i socialpsykiatrien. Hentet fra https://www.holmstrupgaard.rm.dk/siteassets/skole-og-afdelinger/fokus/2021-litteratur-reviewapril.pdf?fbclid=IwAR1liUv-iOSnjsFV-iLPh6jJ9-9d_6xto94EG2uhbSnG96t5IilUneHphAM

Hjortkjær, Chr. (2020). Utilstraekkelig- hvorfor den nye moral gør de unge psykisk syge. Aarhus N: Forlaget Klim

Husen, M. (1996). Det foelles tredje. Hentet fra http://michaelhusen.dk/ socialpaedagogik-ogarbejdsprocesser

Jensen, N.R. (2016). Social Pedagogy in Denmark. Pedagogía Social. Revista Interuniversitaria, núm. 27, enero-junio, pp. 103-127, Sociedad Iberoamericana de Pedagogía Social, Sevilla, España Social pedagogy in the 21.th Century, education policy analysis archives, Vol. 21, No 43, Special Issue, April p. 1-15. https://doi.org/10.7179/PSRI_2016.27.04

Jørgensen, P., Bredkjær, P. \& Nordentoft, M. (2012). Psykiatriens udfordringer. København: Forlaget Munksgaard

Katzenelson, N. et al. (2019). Ny udsathed i ungdomslivet, København: Hans Reitzels Forlag

Kjølner, T. (2004). Teater, drama og kollektive skabelsesprocesser. Drama nr. 3.

Kjølner, T. (2009). Devising og Konceptuel Devising. I L. Kobbernagel (red.): Skuespilleren på arbejde. Frederiksberg: Frydenlund

Kristensen, O.S. \& Hybel, K.A. (2007). Fænomen og virkning - Introduktion til antologien. I O.S. Kristensen. (red.) Mellem Omsorg og Metode. Aarhus C: Systime Profession

Lihme, B. (1988). Socialpaedagogik for børn og unge: et debatoploeg med sarlig henblik på døgninstitutionen.

Aarhus N: SocPol

Lihme, B. (red.) (2015). Det sociales betydning for mennesker med sindslidelse. København: Akademisk Forlag

Linhorst, D.M., Eckert, A. \& Hamilton, G. (2005). Promoting Participation in Organizational Decision Making by Clients with Severe Mental Illness. Social Work 50.1: 21-30.

https://doi.org/10.1093/sw/50.1.21

Ljungberg, Denhov \& Topor, A: (2015). The Art of Helpful Relationships with professionals: A Meta-ethnography of the Perspective of Persons with Servere Mental Illness of the perspective of persons with Servere mental illness. Psychiatr Q 86:471-495. https://doi.org/10.1007/s11126-015$\underline{9347-5}$ 
Ljungberg, A., Denhov, \& Topor, A: (2016). Non-helpful relationships with professionals - a literature review of the perspective of persons with severe mental illness. J Mental Health 25(3): 267-277. https://doi.org/10.3109/09638237.2015.1101427

Mathisen, V., et al. (2016). Whose decision is it anyway? A qualitative study of user participation and how clinicians deal with the patient perspective in mental healthcare, The Mental Health Review 21(4) p. 249-260. https://doi.org/10.1108/MHRJ-01-2016-0003

Murphy, D. \& Joseph, S. (2019) Contributions from the person-centred experiential approach to the field of social pedagogy. Cambridge Journal of Education, 49:2, 181-196.

https://doi.org/10.1080/0305764X.2018.1488946

Priebe, S., Burns, T \& Craig, T.K.J. (2013). The Future of Academic Psychiatry May Be Social. British journal of psychiatry 202.5: 319-320. Web. Paaby, K., Nielsen, B.S. \& Nielsen K.A. (1988). Fremtidsværksteder som foregrebet utopi, Kontext Nr. 51: 4-60. https://doi.org/10.1192/bjp.bp.112.116905

Priebe, S, Dimic, S. Wildgrube, C., Jankovic, J. Cushing, A., McCabe, R. (2011). Good communication in psychiatry - a conceptual review. European Psychiatry 26: 403-407 Priebe, S. (2016). A Social Paradigm in Psychiatry - Themes and Perspectives. Epidemiology and psychiatric sciences 25.6: 521-527. Web. https://doi.org/10.1016/j.eurpsy.2010.07.010

Raffnsøe, S. \& Gudmand-Høyer, M.T. (2004). Michel Foucaults historiske dispositiv analyse. København: Copenhagen Business School

Rise, M. B., Westerlund, H. Bjørgen, D. \& Steinsbekk, A. (2014). Safely cared for or empowered in mental health care? Yes, please. International Journal of Social Psychiatry 60(2): 134-138. https://doi.org/10.1177/0020764012471278

Rose, N. (2019) Interview i A. Görlich, A., M. Pless, N. Katzenelson \& L. Graversen (red.) Udsathed i Ungdomslivet. København: Hans Reitzels Forlag

Rothuizen, J.J. \& Boldsen, P. (2016). Socialpoedagogik i arbejdet med mennesker med sindslidelser. Aarhus Kommune: for Socialpædagogernes Landsforbund hentet fra https://sl.dk/media/4263/socialpaedagogik-i-arbejdet-med-mennesker-med-sindslidelser.pdf

Solbjør M, Rise MB, Westerlund H, Steinsbekk A. (2013) Patient participation in mental healthcare: when is it difficult? A qualitative study of users and providers in a mental health hospital in Norway. Int J Soc Psychiatry, Mar;59(2):107-13. https://doi.org/10.1177/0020764011423464

Sommerseth, R. \& Dysvik, E. (2008). Health professionals' experiences of person-centred collaboration in mental health care. Patient Preference an Adherence, 2:259-269. https://doi.org/10.2147/PPA.S3988

Stern, D.N. (2000). Spcedbarnets interpersonelle verden. København: Hans Reitzels Forlag 
Szatkowski, J. (2019). A Theory of Dramaturgy. Oxon: Routledge.

https://doi.org/10.4324/9781351132114

Tofteng, D. \& Husted, M. (2006). The common third. In: K.A. Nielsen \& L. Svensson. Action Research and Interactive Research. Beyond practice and theory. Maastricht: Shaker Publishing

Torfing, J. (2004). Det stille sporskifte i velfoerdsstaten - en diskursteoretisk

beslutningsprocesanalyse. Aarhus: Akademisk Forlag

Treichler, E.B.H. et al. (2015). The Relevance and Implications of Organizational Involvement for Serious Mental Illness Populations. American Journal of Orthopsychiatry, Vol. 85, no. 4, 352-361. https://doi.org/10.1037/ort0000051

VIBIS (2019). Hentet fra: https://danskepatienter.dk

Warming, H. (2019). Interview i A. Görlich, A., M. Pless, N. Katzenelson \& L. Graversen (red.) Udsathed i Ungdomslivet. København: Hans Reitzels Forlag

Wiberg, M. (2017). Etik og værdier i udøvelse af og dannelse til myndighed. I K.E. Petersen \& T. Erlandsen (red.) Poedagogen som myndighedsperson. København: Samfundslitteratur

Øye, C. \& Skorpen, A. (2010). Miljøterapi som kollektivt eller individrettet fenomen? En etnografisk studie av dagliglivet i et psykiatrisk sykehus i individualismens tidsalder. Vård i Norden, 30 (3), 2530

${ }^{1}$ THE SALAMANCA STATEMENT AND FRAMEWORK FOR ACTION ON SPECIAL NEEDS EDUCATION, Salamanca, Spain, 7-10 June 1994 United Nations Ministry of Educational, Scientific and Education and Science Cultural Organization Spain Convention on the Rights of Persons with Disabilities, United Nations, 2006 WHO 2005: Mental health declaration for Europe WHO 2010: User Empowerment in Mental Health WHO 2013: Mental Health Action Plan 2013-2020 Dansk Kvalitetsmodel på det Sociale Område 2013 og 2015

(Aarhus gentænker Velfærden, Kommune forfra 2016)

${ }^{2}$ Jacob Bundsgaard, Borgmester i Aarhus kommune. Oplæg på Velfærdens Innovationsdag, 28.01.2016

${ }^{3}$ Region Midtjyllands målbillede hentet fra https://www.rm.dk/sundhed/kvalitet-i-region-midtjylland/vi-maler-pakvaliteten

${ }^{4}$ Her: Spiseforstyrrelser, skizofreni, andre psykotiske lidelser, personlighedsforstyrrelser (f.eks. borderline), depressive tilstande, opmærksomhedsforstyrrelser (f.eks. ADHD), autismespektrumforstyrrelser, selvskadende adfærd, angst, OCD og Tourettes syndrom 
${ }^{5}$ Består af en optakt samt tre faser: Materialegenerering, komposition og iscenesættelse (Kjølner, 2004, 2009), hvilket kan overføres til social og pædagogisk kontekst jf. Helm, 2017

${ }^{6}$ Et Dispositiv kan forstås som en sammenvævning af teknologier, vidensformer, strukturer og diskurser, der kan bidrage til at analysere og forstå fremherskende kulturelle, historiske og sociale elementer. Se desuden: Foucault 1982, 2008, 2016; Hamre, 2012; Jensen, 2005; Raffnsøe \& Gudmand-Høyer, 2004; Raffnsøe, Gudmand-Høyer \& Thaning, 2009.

${ }^{7}$ Der er i skrivende stund ikke fundet tilsvarende definition på det sociale område

${ }^{8}$ Refererer til de unge og unge voksne beboere på institutionen Holmstrupgård

${ }^{9}$ Miljøterapi opstod i 1970'erne med udgangspunkt i ønsker om en samfundsmæssig tilgang, demokratiske principper, brugerinddragelse og kreativ samskabelse i recovery-baseret behandling af psykisk sårbare mennesker (Bjerregaard 2007). Den blev dog i Skandinavien hurtigt afløst af en form for individualiseret miljøterapi, som primært bygger på én-til-én alliancen og relationen (dyader) mellem behandler og patient (Schjødt \& Heinskou, 2007). Således er miljøterapi gennem en årrække blevet praktiseret som relationsbehandling indenfor nøje fastlagte strukturer i den psykiatriske og socialpsykiatriske døgnbehandling.

${ }^{10}$ Se også note vii.

${ }^{11}$ Forstået som rekursivt skabende (Helm, 2017, 2020; Szatkowski, 2019) 